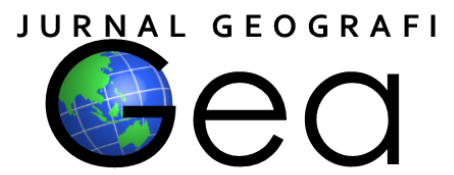

\title{
WILAYAH KERAWANAN LONGSOR DI KECAMATAN PAMIJAHAN KABUPATEN BOGOR
}

\author{
Ana Mariana Ulfah Rahayu ${ }^{1}$, Andri Noor Ardiansyah ${ }^{2}$, Neng Sri Nuraeni ${ }^{3}$ \\ 1,2,3 Program Studi Pendidikan IPS, Fakultas Ilmu Tarbiyah dan Keguruan, UIN Syarif Hidayatullah \\ Jakarta \\ J1. Ir. H.Juanda No.95 Ciputat 15412 Indonesia \\ 1amariana560@gmail.com, ${ }^{2}$ andri.noor@uinjkt.ac.id
}

\begin{abstract}
Landslide is a disaster which often gives a destructive danger whether to our properties or our souls. Besides, it also destroys public facilities which effect on social and economic condition. Generally, a landslide is often caused by nature or human factors. This research goal is to know the distribution of the landslide site spots and the landslide vulnerability level in Pamijahan Bogor. To get the information of its vulnerability and its distribution in maps, which use Geographic Information System ArcGIS 10.1. the research has been conducted by descriptive kuantitative methods, they are field survey and overlay map. Whereas for identifying vulnerable landslide spots, it uses the scoring method. The observed parameters of the landslide vulnerability level are the precipitation, the slope, the height, the type of soil, and land use. The result of the research shows that there are 17 landslide site spots from 2011 to 2015. There are 3 levels for the landslide vulnerabilities (1) The less vulnerability level as wide as 257,79 ha, or 1,85\%; (2) The vulnerable level as wide as 10.624,28 ha or 76,20\%; (3) The most vulnerable as wide as $3.060,26$ ha or $21,95 \%$. It shows that Pamijahan is vulnerable enough to have landslide.
\end{abstract}

Keywords: Landslide, Pamijahan, Scoring, ArcGIS, GIS

\begin{abstract}
ABSTRAK
Longsor merupakan bencana alam yang sering mengakibatkan kerugian harta benda maupun korban jiwa dan rusaknya fasilitas umum yang berdampak pada kondisi sosial dan ekonomi. Penelitian ini bertujuan untuk mengetahui sebaran titik kejadian longsor dan tingkat kerawanan longsor di Kecamatan Pamijahan Kabupaten Bogor. Penelitian dilakukan dengan menggunakan metode Deskriptif Kuantitatif yang terdiri dari survey lapangan dan overlay peta, untuk identifikasi daerah rawan longsor menggunakan metode scoring. Parameter tingkat kerawanan longsor yang diamati adalah curah hujan, kemiringan lereng, ketinggian, jenis tanah, dan penggunaan lahan. Hasil penelitian menunjukkan terdapat 17 sebaran titik kejadian longsor dari tahun 2011 hingga 2015. Untuk tingkat kerawanan longsor terdiri dari tiga kelas yaitu (1) Kelas kurang rawan seluas 257,79 ha atau $1,85 \%$; (2) Kelas rawan seluas $10.624,28$ ha atau 76,20\%; (3) Kelas sangat rawan seluas 3.060,26 ha atau 21,95\%. Hal ini menunjukkan bahwa Kecamatan Pamijahan termasuk ke dalam tingkat yang rawan terjadi longsor.
\end{abstract}

Kata kunci: Longsor, Pamijahan, Scoring, ArcGIS, SIG

\section{PENDAHULUAN}

Longsor merupakan bencana alam yang sering mengakibatkan kerugian harta benda maupun korban jiwa dan rusaknya fasilitas umum yang berdampak pada kondisi sosial dan ekonomi. Longsor ialah perpindahan masa tanah yang bergerak ke bawah atau keluar lereng. Umumnya bencana longsor disebabkan oleh faktor alam, seperti curah hujan yang tinggi dan lereng yang curam. Kegiatan manusia juga dapat mempengaruhi terjadinya longsor, seperti penebangan hutan secara liar dan mendirikan pemukiman di daerah tebing. Hal tersebut akan merusak pola tanah yang ada, karena air tidak akan mampu menyerap ke dalam tanah tanpa adanya tanaman atau pohon.

Menurut Pusat Vulkanologi dan Mitigasi Bencana Geologi (PVMBG) terdapat 21 
kabupaten di Provinsi Jawa Barat yang rawan terjadi longsor, salah satunya ialah Kabupaten Bogor. Dilihat dari data indeks rawan bencana Provinsi Jawa Barat tahun 2011, Kabupaten Bogor berada di posisi ke lima. Menurut Badan Penanggulangan Bencana Daerah (BPBD) Kabupaten Bogor mencatat dari 40 kecamatan yang ada di Kabupaten Bogor, terdapat 16 kecamatan yang sudah tertimpa bencana longsor, salah satunya Kecamatan Pamijahan. BPBD mencatat kejadian bencana longsor di Kecamatan Pamijahan sebanyak 17 kali dari tahun 2011 hingga 2015, artinya setiap tahun selalu terjadi bencana longsor di Kecamatan Pamijahan.

Untuk mengurangi dampak negatif akibat longsor maka perlu diidentifikasi kawasan-kawasan yang rawan longsor sebagai antisipasi untuk mencegah kerugian yang lebih besar. Sistem Informasi Geografis ArcGIS 10.1 digunakan dalam penelitian ini dianggap mampu menyediakan informasi data geospasial setiap objek di permukaan bumi secara cepat dan sekaligus menyediakan sistem analisis keruangan yang akurat. Sehingga dapat diperoleh daerah tingkat kerawanan longsor dan dapat digunakan upaya mitigasi yang bertujuan untuk meminimalisasi bahaya dan kerugian yang ditimbulkan oleh longsor.

Berdasarkan latar belakang diatas, penulis tertarik untuk melakukan penelitian dengan judul "Studi Tingkat Kerawanan Wilayah Longsor di Kecamatan Pamijahan Kabupaten Bogor". Adapun tujuan Penelitian ini untuk: (1) Mengetahui sebaran titik terjadinya longsor di Kecamatan Pamijahan Kabupaten Bogor dengan menggunakan SIG. (2) Menganalisis tingkat kerawanan longsor di Kecamatan Pamijahan Kabupaten Bogor dengan menggunakan SIG.

\section{METODE}

\section{Tempat dan Waktu Penelitian}

Penelitian ini dilakukan di Kecamatan Pamijahan Kabupaten Bogor dapat dilihat pada gambar 1, sedangkan penelitian ini dilakukan selama 5 bulan.

\section{Peralatan Bahan}

a) Peralatan

Peralatan yang digunakan dalam penelitian ini adalah:

- Perangkat Keras (Hardware)

1) Netbook Accer Aspire One D260

2) Printer HP Deskjet

3) GPS (Global Positioning System)

- Perangkat Lunak

1) Microsoft Word 2010

2) Microsoft Excel 2010

3) ArcGIS 10.1

b) Bahan

- DEM (Digital Elevation Model) perekaman tahun 2014 (Sumber: Google Earth Explorer)

- Peta RBI Digital Kecamatan Pamijahan skala 1 : 25.000 tahun 2005 (Sumber: Badan Informasi Geospasial)

- Peta Administrasi Kecamatan Pamijahan (Sumber: BAPPEDA Kabupaten Bogor)

- Peta jenis tanah Kabupaten Bogor tahun 1992 (Sumber: Pusat Penelitian Tanah dan Agroklimat)

- Peta Penggunaan Lahan Provinsi Jawa Barat (Sumber: BAPPEDA Kabupaten Bogor)

- Peta Geologi Kabupaten Bogor tahun 2005 (Sumber: BAPPEDA Kabupaten Bogor)

- Data curah hujan Kecamatan Pamijahan tahun 2011-2015 (Sumber: BMKG dan Stasiun Klimatologi Dramaga Bogor)

- Data monografi Kecamatan Pamijahan tahun 2015 (Sumber: Kantor Pemerintah Kecamatan Pamijahan). 


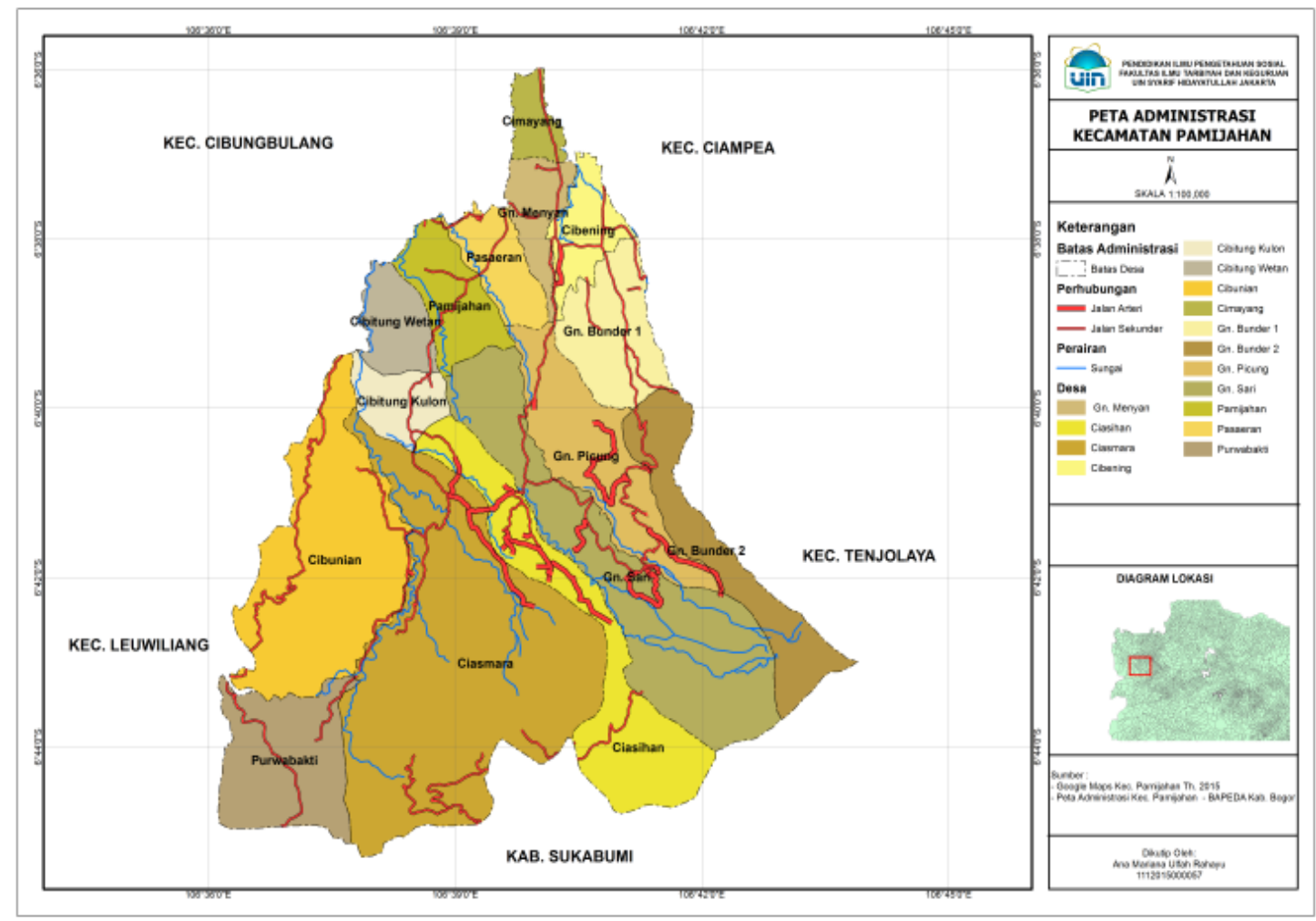

Gambar 1. Peta Administrasi Kecamatan Pamijahan Kabupaten Bogor

\section{Teknik Analisis Data}

Pada tahap analisis data, penulis menggunakan metode overlay peta. Menurut Eko Budiyanto, Overlay merupakan teknik tumpang susun peta tematik yang menjadi indikator dalam proses analisis spasial. Selanjutnya, dilakukan analisis dengan teknik skoring dan pembobotan. Skoring dan pembobotan merupakan nilai yang berikan terhadap poligon peta untuk mempresentasikan tingkat kedekatan, keterkaitan, atau beratnya dampak tertentu pada suatu fenomena secara spasial. Skoring diberikan melalui pembobotan dan penilaian terhadap parameter dan indikator-indikator yang mempengaruhi kerawanan longsor. Untuk melakukan proses overlay peta dan skoring, penelitian ini memanfaatkan Sistem
Informasi Geografis (SIG) software ArcGIS 10.1. berikut parameter dan indikator kerawanan longsor beserta nilai dapat dilihat pada tabel 1 .

Dari parameter tabel 1, lalu dibuatlah Kriteria tingkat kerawanan longsor berdasarkan Pusat Vulkanologi dan Mitigasi Bencana Geologi (PVMBG). Tingkat kerawanan longsor dibagi menjadi tiga kelas, yaitu:

1. Tidak rawan

2. Rawan

3. Sangat rawan

Dari semua parameter kerawanan longsor, maka didapatkan suatu persamaan untuk menghitung nilai skoring kerawanan longsor di suatu wilayah sebagai berikut.

$$
\begin{aligned}
& \text { Skor }=(30 \% \times \text { parameter curah hujan })+(25 \% \times \text { parameter kemiringan } \\
& \text { lereng })+(10 \% \times \text { parameter ketinggian })+(15 \% \times \text { parameter jenis tanah })+ \\
& (20 \% \times \text { parameter penggunaan lahan })
\end{aligned}
$$


Tabel 1. Parameter Rawan Longsor dan Nilai

\begin{tabular}{|c|c|c|c|}
\hline No & Variable & Kriteria & Nilai \\
\hline 1 & Kelerengan & 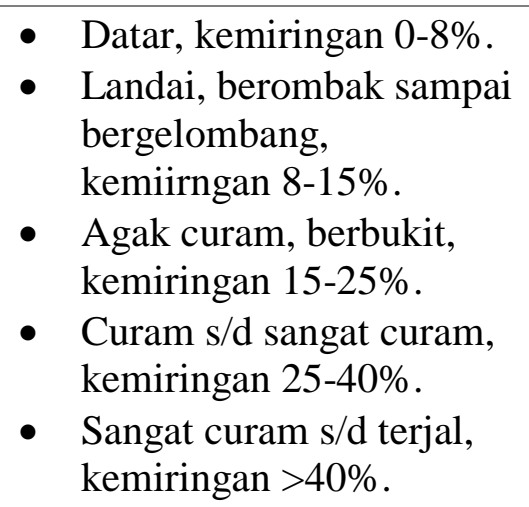 & $\begin{array}{l}3 \\
4 \\
5\end{array}$ \\
\hline 2 & Ketinggian & $\begin{array}{l}\text { Dataran rendah 0-1000 } \\
\text { mdpl } \\
\text { - } \quad \text { Dataran tinggi 1000-2000 } \\
\text { mdpl } \\
\text { - Pegunungan > } 2000 \text { mdpl }\end{array}$ & $\begin{array}{l}1 \\
2 \\
3\end{array}$ \\
\hline 3 & Curah Hujan & $\begin{array}{l}\text { - Curah Hujan <1000 } \\
\text { mm/thn } \\
\text { - } \text { Curah Hujan 1000-1500 } \\
\text { mm/thn } \\
\text { - } \text { Curah Hujan 1500-2000 } \\
\text { mm/thn } \\
\text { - Curah Hujan 2000-2500 } \\
\text { mm/thn } \\
\text { - Curah Hujan >2500 } \\
\text { mm/thn }\end{array}$ & $\begin{array}{l}1 \\
2 \\
3 \\
4 \\
5\end{array}$ \\
\hline 4 & Jenis Tanah & $\begin{array}{ll}\text { - } & \text { Aluvial } \\
\text { - } & \text { Mediteran, Brown Forest, } \\
& \text { Non calcic brown } \\
\text { - } & \text { Andosol } \\
\text { - } & \text { Litosol }\end{array}$ & $\begin{array}{l}1 \\
2 \\
3 \\
4\end{array}$ \\
\hline 5 & $\begin{array}{l}\text { Penggunaan } \\
\text { Lahan }\end{array}$ & $\begin{array}{ll}\text { - } & \text { Tubuh Air } \\
\text { - Hutan } \\
\text { - Kebun } \\
\text { - Tegalan,Sawah, } \\
\text { - Pemukiman }\end{array}$ & $\begin{array}{l}1 \\
2 \\
3 \\
4 \\
5\end{array}$ \\
\hline
\end{tabular}

Sumber: Jefri Ardian Nugroho (2008)

Setelah dilakukan penghitungan total skor parameter kerawanan longsor sesuai dengan nilai bobotnya masing-masing, maka didapatkan hasil tingkat kerawanan longsor di Kecamatan Pamijahan.

Tabel 2. Skor Kumulatif Tingkat Kerawanan Longsor

\begin{tabular}{lcc}
\hline No & $\begin{array}{c}\text { Skor } \\
\text { Kumulatif }\end{array}$ & $\begin{array}{c}\text { Status/Klasifikasi } \\
\text { Bencana }\end{array}$ \\
\hline $\mathbf{1}$ & $\leq 2,5$ & Kurang Rawan \\
\hline
\end{tabular}

\begin{tabular}{lll}
$\mathbf{2}$ & $\geq 2,6-\leq 3,6$ & Rawan \\
\hline $\mathbf{3}$ & $\geq 3,7$ & Sangat Rawan \\
\hline
\end{tabular}

Sumber: Pusat Vulkanologi dan Mitigasi Bencana Geologi (2005)

\section{HASIL DAN PEMBAHASAN Deskripsi Data}

a) Gambaran Umum Lokasi Penelitian Kecamatan Pamijahan terletak pada koordinat $106^{\circ} 38^{\prime} 00^{\prime \prime}$ sampai $106^{\circ} 42^{\prime} 00^{\prime \prime}$ 
Bujur Timur dan 6 $6^{\circ} 38^{\prime} 00^{\prime}$ sampai 6 $6^{\circ} 44^{\prime} 00^{\prime \prime}$ Lintang Selatan. Secara administratif luas wilayah Kecamatan Pamijahan terbagi menjadi 15 desa. Adapun batas wilayah Kecamatan Pamijahan adalah Batas wilayah Kecamatan Pamijahan di sebelah utara berbatasan dengan Kecamatan Cibungbulang, sebelah timur berbatasan dengan Kecamatan Tenjolaya, sebelah selatan berbatasan dengan Kecamatan Parung Kuda Kabupaten Sukabumi, dan sebelah barat berbatasan dengan Kecamatan Leuwiliang.

b) Kondisi Fisik Lokasi Penelitian

- Curah Hujan

Secara umum, keadaan iklim di Kecamatan Pamijahan hampir sama dengan iklim di Kabupaten Bogor. Suhu di Kecamatan Pamijahan rata-rata $27^{\circ}-28^{\circ} \mathrm{C}$. Rata-rata curah hujan tahunan sebesar 363,166 $\mathrm{mm} /$ tahun.

- Kemiringan Lereng

Kecamatan Pamijahan memiliki topografi yang beragam meliputi dataran tinggi/perbukitan sampai pada dataran rendah. Pada kemiringan lereng 0-8\% dengan kondisi lereng yang datar memiliki luas area 47,26 Ha. Kemiringan lereng 8-15\% dengan kondisi lereng landai memiliki luas area 6.500,98 Ha. Kemiringan $15-25 \%$ dengan kondisi lereng yang agak curam seluas $4.761 \mathrm{Ha}$. Kemiringan $25-40 \%$ dengan kondisi lerek sangat curam memiliki luas area 1.342,17 Ha. Dan kemiringan lereng $>40 \%$ dengan kondisi lereng yang sangat curam seluas 24,32 Ha.

\section{- Ketinggian}

Kecamatan Pamijahan juga memiliki ketinggian yang bervariasi yaitu antara 1000 2000 meter. Ketinggian di Kecamatan Pamijahan dibagi menjadi tiga kelas, yaitu ketinggian $0-1000$ meter seluas 9.344 ha merupakan ketinggian yang paling dominan. Ketinggian selanjutnya yaitu $1000-2000$ meter seluas 3.333 ha. Ketinggian $>2000$ meter seluas 5 ha.

Tabel 3. Penyebaran Lokasi Terjadi Longsor di Kecamatan Pamijahan

\begin{tabular}{cccc}
\hline No. & \multicolumn{1}{c}{ Lokasi Kejadian Longsor } & \multicolumn{1}{c}{ Titik Koordinat } & Waktu Kejadian \\
\hline $\mathbf{1}$ & Ciasihan/Kp. Gunung Menir RT 01/07 & $06^{\circ} 41^{\prime} 37,8^{\prime \prime} \mathrm{LS}$ & 18 Oktober 2011 \\
& & $106^{\circ} 39^{\prime} 53,9^{\prime \prime} \mathrm{BT}$ & \\
\hline $\mathbf{2}$ & Pasarean/Kp. Lebak Sari RT 01/09 & $06^{\circ} 38^{\prime} 57,5^{\prime} \mathrm{LS}$ & 16 April 2012 \\
& & $106^{\circ} 39^{\prime} 58,6^{\prime \prime} \mathrm{BT}$ & \\
\hline $\mathbf{3}$ & Purwabakti/Kp. Taneuh Beureum & $06^{\circ} 41^{\prime} 22,4^{\prime \prime} \mathrm{LS}$ & 20 Maret 2013 \\
& & $106^{\circ} 38^{\prime} 53,33^{\prime \prime} \mathrm{BT}$ & \\
\hline
\end{tabular}

Dari hasil pengolahan dapat diketahui bahwa di Kceamatan Pamijahan jenis tanahnya terdiri dari Aluvial memiliki luas $3.553 \mathrm{Ha}$. tanah Andosol di Pamijahan seluas 4.028 Ha. Tanah litosol memiliki luas 4.114 Ha. Jenis tanah Mediteran memiliki luas 1.108 Ha. sedangkan untuk jenis batuan terdiri dari (1) Qvep, merupakan batuan hasil lava gunung api Endut, Prabakti seluas 2.653 ha. (2) Qvl, merupakan lava gunung api Gunung Salak Bogor seluas 144 ha. (3) Qvb, merupakan batuan gunung api Salak Bogor seluas 2.460 ha. (4) Qvst, merupakan batuan dari gunung api Salak Bogor juga dengan luas 5.150 ha. (5) Qvu, merupakan batuan gunung api Tua seluas 2.233 ha.

\section{- Penggunaan Lahan}

Penggunaan lahan pada Kecamatan Pamijahan terdapat lima penggunaan lahan terdiri dari perkebunan, hutan, pemukiman, sawah, dan sungai. Penggunaan lahan yang paling luas didominasi oleh perkebunan seluas 7.634 ha. selanjutnya hutan seluas 3.411 ha. Persawahan seluas 3.777 ha. Pemukiman seluas 677 ha, dan sungai seluas 86 ha.

\section{Sebaran Lokasi dan Tingkat Kerawanan Longsor}

Berdasarkan data yang diperoleh dari Badan Penanggulangan Bencana Daerah (BPBD) Kabupaten Bogor terdapat 17 kejadian longsor dari tahun 2011 hingga tahun 2015. Dari data BPBD tersebut, penulis mencoba melakukan observasi ke lokasi yang pernah mengalami longsor dengan menggunakan GPS untuk melihat titik koordinat lokasi kejadian longsor. hasil observasi penyebaran lokasi kejadian longsor dapat dilihat pada tabel 3.

Dari 17 kejadian longsor tersebut, maka penulis membuat peta sebaran kejadian longsor di Kecamatan Pamijahan dapat dilihat pada gambar 2 . 
Rahayu A. M. U., Ardiansyah A. N., Nuraeni N. S., Wilayah Kerawanan Longsor...

\begin{tabular}{|c|c|c|c|}
\hline 4 & Gunungsari/Kp. Lokapurna RT 03/09 & $\begin{array}{l}06^{\circ} 41^{\prime} 53,99^{\prime \prime} \mathrm{LS} \\
106^{\circ} 37^{\prime} 42,99^{\prime} \mathrm{BT}\end{array}$ & 13 Mei 2013 \\
\hline 5 & Cibunian Rw 05 & $\begin{array}{l}06^{\circ} 40^{\prime} 33,6^{\prime \prime} \mathrm{LS} \\
106^{\circ} 37^{\prime} 42,99^{\prime \prime} \mathrm{BT}\end{array}$ & 4 November 2013 \\
\hline 6 & Cibunian/Kp. Cipatat II RT 02/06 & $\begin{array}{l}06^{\circ} 40^{\prime} 54,99^{\prime} \mathrm{LS} \\
106^{\circ} 38^{\prime} 06,8^{\prime} \mathrm{BT}\end{array}$ & 21 Januari 2014 \\
\hline 7 & Ciasmara/Kp. Kebon Alas RT 01/09 & $\begin{array}{l}06^{\circ} 41^{\prime} 35,1 \text { ' LS } \\
106^{\circ} 39^{\prime} 21,8^{\prime \prime} \mathrm{BT}\end{array}$ & 11 Januari 2014 \\
\hline 8 & Gunung Menyan/Kp. Kananga RT 02/04 & $\begin{array}{l}06^{\circ} 37^{\prime} 14,0 ” \mathrm{LS} \\
106^{\circ} 40^{\prime} 28,99^{\prime} \mathrm{BT}\end{array}$ & 2 Februari 2014 \\
\hline 9 & Ciasmara/Kp. Cibeureum RT 04/09 & $\begin{array}{l}06^{\circ} 41^{\prime} 37,99^{\prime \prime} \mathrm{LS} \\
106^{\circ} 39^{\prime} 25,0^{\prime \prime} \mathrm{BT}\end{array}$ & 1 Februari 2014 \\
\hline 10 & $\begin{array}{l}\text { Gunung Bunder I/Kp. Tegal Leumeung } \\
\text { RT 04/01 }\end{array}$ & $\begin{array}{l}06^{\circ} 38^{\prime} 35,0^{\prime \prime} \mathrm{LS} \\
106^{\circ} 40^{\prime} 49,8^{\prime \prime} \mathrm{BT}\end{array}$ & 4 Februari 2014 \\
\hline 11 & Purwabakti/Kp. Campedak RT 04/02 & $\begin{array}{l}06^{\circ} 41^{\prime} 22,1 \text { ' LS } \\
106^{\circ} 38^{\prime} 41,9 \text { 'BT }\end{array}$ & 8 April 2014 \\
\hline 12 & Ciasmara/Kp. Parabakti Pasar Rt 01/07 & $\begin{array}{l}06^{\circ} 41^{\prime} 12,2 \text { "' LS } \\
106^{\circ} 38^{\prime} 54,8^{\prime \prime} \mathrm{BT}\end{array}$ & 8 April 2014 \\
\hline 13 & Gunung Sari/Kp. Lebaksari RT 01/01 & $\begin{array}{l}06^{\circ} 39^{\prime} 20,3 ” \mathrm{LS} \\
106^{\circ} 39^{\prime} 42,5^{\prime \prime} \mathrm{BT}\end{array}$ & 8 April 2014 \\
\hline 14 & Cibunian RW 07 & $\begin{array}{l}06^{\circ} 40^{\prime} 50,77^{\prime} \mathrm{LS} \\
106^{\circ} 38^{\prime} 04,3 \text { ”'BT }\end{array}$ & 28 Agustus 2014 \\
\hline 15 & $\begin{array}{l}\text { Gunung Picung/Kp. Pasar Kemis RT } \\
02 / 03\end{array}$ & $\begin{array}{l}06^{\circ} 39^{\prime} 03,3 \text { " LS } \\
106^{\circ} 40^{\prime} 10,99^{\prime \prime} \mathrm{BT}\end{array}$ & 1 Desember 2014 \\
\hline 16 & $\begin{array}{l}\text { Cibitung Kulon/Kp. Kaung Gading RT } \\
01 / 02\end{array}$ & $\begin{array}{l}06^{\circ} 39^{\prime} 36,5^{\prime \prime} \mathrm{LS} \\
106^{\circ} 38^{\prime} 38,99^{\prime \prime} \mathrm{BT}\end{array}$ & 28 Desember 2014 \\
\hline 17 & Cibunian/Kp. Muara II RT 02/01 & $\begin{array}{l}06^{\circ} 42^{\prime} 36,5^{\prime \prime} \mathrm{LS} \\
106^{\circ} 38^{\prime} 00,8^{\prime \prime} \mathrm{BT}\end{array}$ & 21 Desember 2015 \\
\hline
\end{tabular}

a. Daerah Kurang Rawan Longsor

Daerah kurang rawan longsor adalah daerah yang memiliki potensi longsor yang kecil. Sebab, dari hasil pengolahan data menunjukkan nilai $\leq 2,5$. Daerah yang termasuk kategori kurang rawan longsor seluas 257,79 Ha atau sekitar $1,85 \%$. Desa yang termasuk kategori kurang rawan hanya sebagian kecil saja, yaitu desa Cimayang, Gunung Menyan, Cibunian, Pasarean, Gunung Sari, dan desa Gunung Bunder 2.

b. Daerah rawan longsor

Daerah rawan longsor merupakan daerah yang memiliki potensi longsor sedang. Dari hasil penghitungan scoring parameter longsor sebesar $\geq 2,6-\leq 3,6$. Daerah yang termasuk kategori rawan longsor seluas $10.624,28 \mathrm{Ha}$ atau $76,20 \%$. Desa yang termasuk kategori
Sumber: Hasil Penelitian 2016

rawan tersebar di desa Cimayang, Gunung Menyan, Cibening, Pasarean, Pamijahan, Cibitung Wetan, Cibitung Kulon, Gunung Bunder 1, Gunung Picung, Cibunian, Purwabakti, sebagian wilayah Gunung Sari, dan sebagian wilayah Gunung Bunder 2.

c. Daerah Sangat Rawan Longsor

Daerah sangat rawan longsor merupakan daerah yang paling berpotensi mengalami longsor. Hal ini dikarenakan hasil dari penghitungan pada nilai-nilai parameter yang diatas nilai rata-rata dengan total skor mencapai angka $\geq 3,7$. Daerah sangat rawan longsor memiliki luas 3.060,26 $\mathrm{Ha}$ atau $21,95 \%$ tersebar di wilayah sebagian Purwabakti, sebagian Cibunian, Ciasmara, Ciasihan, Gunung Sari, dan desa Gunung Bunder 2. 


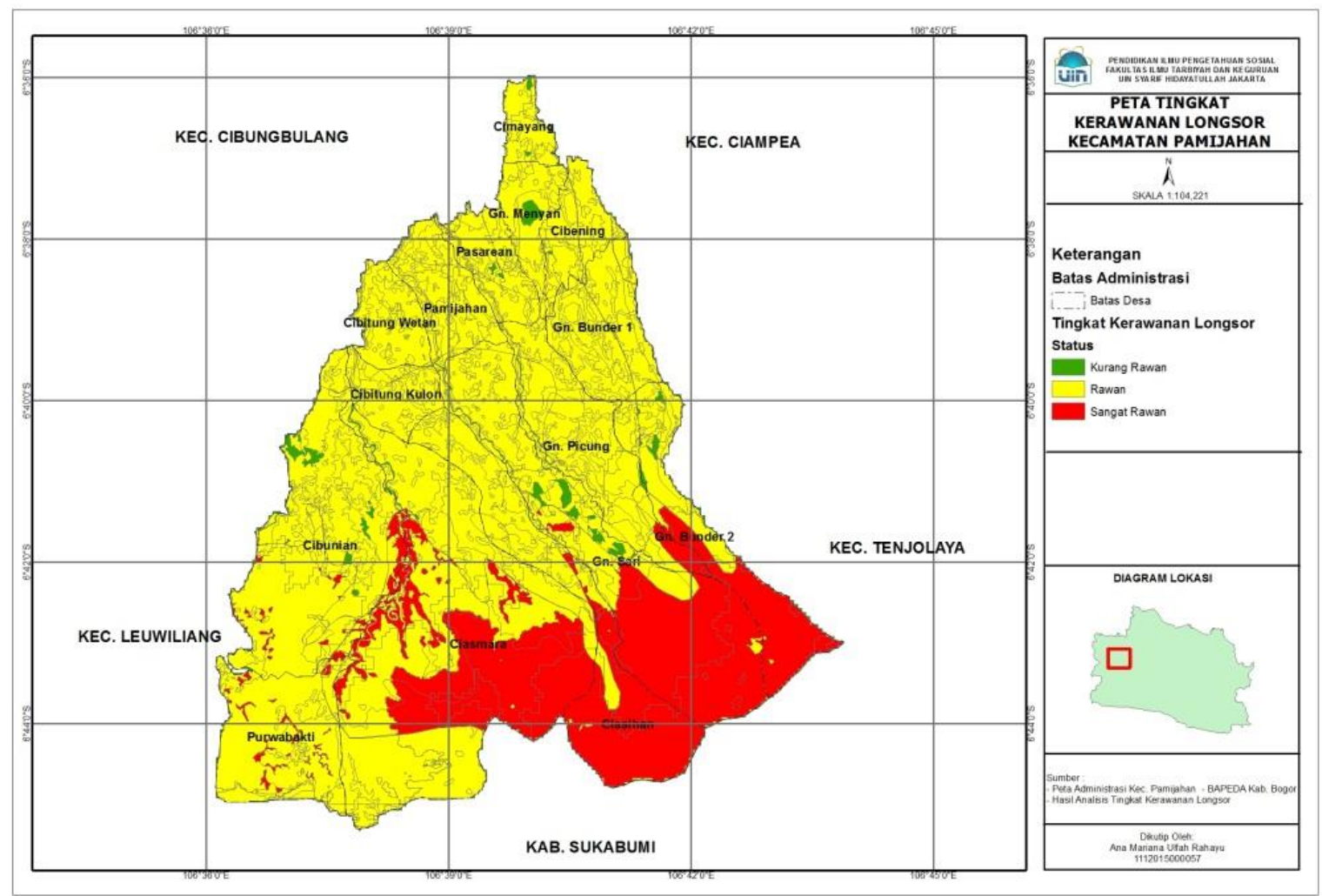

Gambar 2. Peta Tingkat Kerawanan Longsor di Kecamatan Pamijahan Kabupaten Bogor

\section{SIMPULAN}

Berdasarkan dari apa yang telah dibahas pada penelitian ini maka dapat ditarik beberapa kesimpulan, antara lain sebagai berikut:

- Terdapat 17 titik kejadian longsor di Kecamatan Pamijahan dari tahun 2011 hingga tahun 2015.

- Tingkat kerawanan longsor di Kecamatan Pamijahan Kabupaten Bogor termasuk ke dalam tingkat yang cukup rawan longsor dengan luas $10.624,28$ ha $(76,20 \%)$ disertai Faktor-faktor utama terjadinya longsor di Kecamatan Pamijahan yaitu: parameter jenis tanah yaitu jenis tanah alluvial dan litosol dengan tekstur tanah lempung liat dan berpasir. Parameter penggunaan lahan yaitu jenis perkebunan, persawahan, dan pemukiman. Kondisi daerah rawan longsor terutama tebing pada jalan raya tanpa adanya bangunan konservasi untuk menahan longsor. Parameter kemiringan lereng dan ketinggian yaitu kondisi lereng yang curam hingga sangat curam dengan bentang lahan berbukit hingga bergunung. Parameter curah hujan yaitu kondisi tipe iklim sedang dan curah hujan rat-rata $363,166 \mathrm{~mm} /$ tahun.

\section{REKOMENDASI}

Beberapa upaya yang dapat dilakukan dalam memperkecil tingkat kemungkinan terjadinya peningkatan tingkat daerah rawan longsor ialah sebagai berikut:

- Perlu dilakukan penanaman vegetasi keras (pohon) dengan akar kuat sesuai dengan kondisi fisik wilayah.

- Perlu mendirikan bangunan konservasi seperti teras tebing untuk penahan tebing curam yang berada di jalan raya.

- Kerjasama antara pemerintah dan masyarakat setempat dalam mitigasi pencegahan longsor perlu terus dibina dan ditingkatkan.

- Rencana pemerintah untuk merelokasi penduduk yang bertempat tinggal pada kawasan rawan longsor perlu segera direalisasikan untuk mencegah timbulnya korban jiwa pada bencana yang akan datang.

Dengan adanya penelitian ini, baik masyarakat maupun pemerintah lebih waspada dan tanggap terhadap bahaya longsor. peta 
Rahayu A. M. U., Ardiansyah A. N., Nuraeni N. S., Wilayah Kerawanan Longsor... 8

kerawanan longsor akan dijadikan sebagai early warning system (peringatan dini) pada wilayah rawan terjadi longsor.

\section{DAFTAR PUSTAKA}

Arikunto, Suharsimi. Prosedur Penelitian; Suatu Pendekatan Praktik, Jakarta: PT Rineka Cipta, 2006.

Budiyanto, Eko. Sistem Informasi Geografis dengan Arc View GIS, Yogyakarta: CV. Andi Offset, 2010.

Departemen Energi dan Sumber Daya Mineral, Pengenalan Gerak Tanah, Vulcanological Survey of Indonesia, 2005.

Effendi, Ahmad Danil. Identifikasi Kejadian Longsor Dan Penentuan Faktor-Faktor Utama Penyebabnya Di Kecamatan Babakan Madang Kabupaten Bogor, Skripsi Departemen Manajemen Hutan Fakultas Kehutanan Institut Pertanian Bogor, 2008.

Faisal, Arif. Indarto. Tutorial Ringkas ArcGIS10, Yogyakarta: CV. Andi Offset, 2013.

Hardiyatmo, Hary Christiady, Tanah Longsor dan Erosi, Yogyakarta: Gadjah Mada University Press, 2012.

Indrasmoro, Gigih Prastyo. Geographic Information System (GIS) Untuk Deteksi Daerah Rawan Longsor Studi Kasus Di Kelurahan Karang Anyar Gunung Semarang, Jurnal Universitas Dian Nuswantoro Semarang, 2013.

Nandi, Modul Longsor, Jurusan Pendidikan Geografi FPIPS-UPI, 2007.

Nugroho, Jefri Ardian. Pemetaan Daerah Rawan Longsor dengan Penginderaan Jauh dan Sistem Informasi Geografis, Jurnal ITS-Sukolilo, Surabaya, 2008.

Paimin, Teknik Mitigasi Banjir dan Longsor, Tropenbos International Indonesia Programme, 2009.
Peraturan Menteri Pekerjaan Umum No. 22 Tahun 2007 tentang Pedoman Penataan

Ruang Kawasan Rawan Bencana Longsor

Plummer, Physichal Geology $11^{\text {th }}$ Edition. New York: McGraw-Hill, 2007.

Sholahudin, Muhamad, SIG Untuk Memetakan Daerah Banjir dengan Metode Skoring dan Pembobotan, Jurnal Fasilkom, Udinus, Jawa Tengah, 2005.

Sodikin. Sistem Informasi Geografis dan Penginderaan Jauh. Ciputat: UIN Syarif Hidayatullah Jakarta, 2015.

Sriyono, Agus. Identifikasi Kawasan Rawan Bencana Longsor Kecamatan Banyubiru, Kabupaten Semarang, Skripsi Fakultas Ilmu Sosial Universitas Negeri Semarang, 2012.

Sugandi, Dede, Modul SIG, (Jurusan Pendidikan Geografi - FPIPS UPI, 2009.

Sugiyono, Metode Penelitian Kuantitatif Kualitatif dan $R \& D, \quad$ Bandung: Alfabeta,2006.

Todingan, P. Melisa. Pemetaan Daerah Rawan Longsor di Wilayah Sub DAS Tondano degan Sistem Informasi Geografis. Jurnal Universitas Sam Ratulangi, 2014.

Undang-undang RI No. 24 Tahun 2007 tentang Penanggulangan Bencana.

Varnes, J. David, Landslide Hazard Zonation: A Review of Principles and Practice, Paris: United Nations Educational, 1984.

Wibowo, Agus. Identifikasi Wilayah Rentan Longsor di Kecamatan Cicalengka, Kabupaten Bandung, Skripsi Universitas Indonesia, 2009.

Yuniarto, Dwi S. Kesesuaian Penggunaan Lahan Berdasarkan Tingkat Kerawanan Longsor Di Kabupaten Semarang, Tesis Program Pascasarjana Universitas Diponegoro Semarang, 2010. 